\title{
Application of Root Maceration of Common Weeds: T. diversifolia and S. jamaicensis for Phytoremediation of Ohaji Egbema Crude Oil Polluted Soils
}

\author{
Amadi, P.U ${ }^{1, *}$, Agomuo, E.N ${ }^{2}$, Akpobasaha N.A ${ }^{1}$, Njoku, U.C ${ }^{1}$ \\ ${ }^{1}$ Department of Biochemistry, University of Port Harcourt, Choba Rivers State, Nigeria \\ ${ }^{2}$ Department of Biochemistry, Imo State University Owerri, Imo State, Nigeria
}

Copyright $\bigcirc 2017$ by authors, all rights reserved. Authors agree that this article remains permanently open access under the terms of the Creative Commons Attribution License 4.0 International License

\begin{abstract}
This study examined the remediation of crude oil polluted soils obtained from Ohaji Egbema Imo State Nigeria using macerated roots of T. diversifolia (TD) and S. jamaicensis (SJ). The soil pH levels, PAHs (Polycyclic aromatic hydrocarbons) and TPH (Total petroleum hydrocarbons) contents, and catalase and peroxidase activities were evaluated. Thirty-two polyethene bags containing $300 \mathrm{~g}$ of soil samples were divided into eight groups of quadruplicates. Group 1 were the unpolluted soil samples (USS), group 2; polluted soil samples (PSS) without remediation, group 3; PSS containing $250 \mathrm{~g}$ of TD, group 4; PSS containing $500 \mathrm{~g}$ of TD, group 5; PSS containing $250 \mathrm{~g}$ of SJ, group 6; PSS containing $500 \mathrm{~g}$ of SJ, group 7; PSS containing 250g of the mixture of TD and SJ (1:1) and group 8; PSS containing 500g of the mixture of TD and SJ (1:1). At all experimental periods, the $\mathrm{pH}$ of the PSS without remediation was significantly lower than the USS. The $500 \mathrm{~g}$ TD completely normalized the altered $\mathrm{pH}$ of the PSS on the 4th week, comparable to the results of the 12th week. The PAH (Polycyclic aromatic hydrocarbons) levels in the group 5 and 7 on the 1st day were not significantly different from the PAH of the group 2. Group $3,4,7$, and 8 produced the best PAH lowering effects on the polluted soils on the 8th week, which compared to the results of the 12th week. At all experimental periods, $500 \mathrm{~g}$ of TD provided the most effective for TPH reduction of the polluted soils. Results for the enzyme activities showed a significantly decreased $(\mathrm{p}<0.05)$ catalase and peroxidase levels of the polluted soils when compared to the USS. Both the 1st day and 1st week recorded similar catalase activities in all groups except group 5, while group 4-8 recorded significantly increased catalase activities from the $4-12$ th week. For the 1st day, 1st week, and 4th week, increasing the amount of the plants from $250 \mathrm{~g}-500 \mathrm{~g}$ had no effect on the peroxidase levels of the soils, while a quantity dependent significant increase in peroxidase
\end{abstract}

levels was observed only for group 7 and 8 on the 8 th and 12th weeks. The 500g TD produced the most significant restorative effect on the polluted soils. This study has shown the extensive remediation produced by TD on crude oil polluted soils of Ohaji Egbema.

Keywords T. diversifolia, S. jamaicensis, Remediation, Enzymes, Hydrocarbons

\section{Introduction}

The soil is an essential part of the terrestrial ecosystem, and as well, central to production activities in agriculture [1]. The processes that occur in the soils are linked to several abiotic and biotic ecosystem components, hence its proper functioning is important to maintain the nutrient biochemical cycles. The importance of soil to human existence, especially for agriculture, cannot be overemphasized, and has been subjected to various forms of abuse, such as deposition of petroleum by products, petroleum spillage, waste disposal and other contaminants [2]. Polycyclic aromatic hydrocarbons are by products that result from incomplete breakdown of petroleum products, organic materials, fossil fuels, and various industrial activities [3]. PAHs contain many fused rings and are regarded as very serious environmental contaminants [4]. Evaluation of PAHs has recently attracted various interests as a result of their persistent, toxic and carcinogenic characteristics [5]. Rauckyte et al. [6] defined Total Petroleum Hydrocarbons (TPH) as the detectable amount of petroleum based hydrocarbons in the environment, and the human toxicity of these hydrocarbons depend on their physical and chemical nature. Costello, [7] has reported various toxicities of TPH related to the circulatory, nervous, 
reproductive, and endocrine system. Furthermore, to comprehend soil functioning and to prevent both anthropogenic and natural causes of soil damage, it is necessary to develop suitable tools that can predict and assess soil changes. Soil enzymes are among the important biological indicators of soil damage, since they can indicate the soil's potentials to support the biochemical processes and fertility [8]. However, the activities of these enzymes can be affected by natural occurrences like physicochemical properties of the soil, geographic location, seasonal changes, and organic matter content, by affecting both the persistence of the microorganisms and the enzyme production. Also, Gianfreda and Bollag [9] observed that environmental pollutants such as heavy metals, fertilizers, PAHs, and pesticides could disrupt the structural and chemical integrity of the soil thus influencing the abundance of microorganisms, and the suppression or enhancement of the activities of the soil enzymes.

Ohaji Egbema is a Local Government Area located south west of Imo State, known as an oil rich region. Ohaji Egbema borders Owerri in East, Rivers State in the South West, and Oguta in the North.The region boasts of major oil companies such as Agip, Chevron, and Shell Petroleum Nigeria, and has been subject to numerous cases of crude oil spillage, the latest occurring in 2015. Abbey and Anthony [10] documented the occurrence of 20 incidences of crude oil spillage in Ohaji Egbema from 1973-2004, causing far reaching losses of biodiversity, and destruction of habitat as a consequence of crude oil mediated soil degradation [11]. It is suggested that both physical and chemical treatment methods are in most cases left unutilized due to high cost of operation, and ineffectiveness in the removal of contaminants. On the other hand, Balba et al. [12] mentioned that biological approaches or bioremediation involving plants and microorganisms ensure complete breakdown of toxic compounds into harmless products with even greater environmental benefits. The applicability of plants and other biological treatments for the effective and efficient removal have been studied [13, 14]. Soil amendments describes the addition of materials such as fertilizers and organic products to the soil to improve the nutrient capacity and physical quality such as $\mathrm{pH}$ optimization, increased organic matter, better water holding capacity, restored microbial colonies and mitigating soil compaction. This implies that the process of soil amendment encourages remediation, revegetation and revitalization of contaminated sites. In this study, we used the macerated roots of TD and SJ; two rampantly occurring weeds, ensures that it neither causes food shortage nor hampers biodiversity, since they are weeds with high abundance. The aim of this study was to determine the effect of soil amendment on crude oil contaminated soils from Ohaji Egbema L.G.A in Imo State Nigeria, using macerated roots of Tithonia diversifolia and Strachytarpheta jamaicensis.

\section{Materials and Methods}

\subsection{Sample Collection and Identification}

Polluted soils used as test samples were collected using an Auger, from Obokofia, in Ohaji Egbema L.G.A while the samples not polluted were collected at the outskirts of Egbema. All oil samples were collected within $10 \mathrm{~cm}$ depth of the top soils, and put in clean polyethene bags for storage, pending further experimentation. TD and SJ were obtained from cultivated farmlands in Owerri Imo State Nigeria, and were taken to the Department of Plant Science and Biotechnology, Imo State University for identification, and afterwards, the roots were macerated with a knife.

\subsection{Experimental Design}

A total of 32 polyethylene bags containing soil samples $(300 \mathrm{~g})$ where divided into eight groups of quadruplicates. The groups include;

Group 1 (G1): unpolluted soil samples

Group 2 (G2): Polluted soil samples not subjected to any remediation

Group 3 (G3): Polluted soil samples containing $250 \mathrm{~g}$ of macerated roots of TD

Group 4 (G4): Polluted soil samples containing $500 \mathrm{~g}$ of macerated roots of TD

Group 5 (G5): Polluted soil samples containing $250 \mathrm{~g}$ of macerated roots of SJ

Group 6 (G6): Polluted soil samples containing $500 \mathrm{~g}$ of macerated roots of SJ

Group 7 (G7): Polluted soil samples containing $250 \mathrm{~g}$ of macerated roots of the mixture of TD and SJ (1:1)

Group 8 (G8): Polluted soil samples containing $500 \mathrm{~g}$ of macerated roots of the mixture of TD and SJ (1:1)

The soil samples were spread evenly out on each of the polyethene bags before the macerated roots were dispersed on the soil samples. Homogeneous soil samples were analyzed for $\mathrm{pH}, \mathrm{PAH}$ and TPH levels, and catalase and peroxidase activities after $24 \mathrm{~h}, 1$ week, 4 weeks, 8 weeks and 12 weeks. Soil $\mathrm{pH}$ was measured in a suspension of 1:2 soils to water ratio using calibrated $\mathrm{pH}$ meter [14].

\subsection{Sample Processing}

\subsubsection{Extraction}

The soil sample $(2 \mathrm{~g})$ was weighed into a clean extraction container. Exactly $10 \mathrm{ml}$ of pentane which served as the extraction solvent was added into the samples and mixed thoroughly and allowed to settle. The mixtures were then carefully filtered into clean solvent rinsed extraction bottles using filter paper fitted into Buchner funnels. The extracts were concentrated to $2 \mathrm{ml}$ and then transferred for separation. 


\subsubsection{Separation and Analysis (Essien et al., [15])}

Precisely $1 \mathrm{~cm}$ of moderately packed glass wool was placed at the bottom of $10 \mathrm{~mm}$ ID x $250 \mathrm{~mm}$ loop chromatographic column. Slurry of $2 \mathrm{~g}$ activated silica in $10 \mathrm{ml}$ methylene chloride was prepared and placed into the chromatographic column.

To the top of the column was added $0.5 \mathrm{~cm}$ of sodium sulphate. The column was then pre-eluted with $20 \mathrm{ml}$ of pentane and this was allowed to flow through the column at a rate of about 2 min until the liquid in the column was just above the sulphate layer. Immediately $1 \mathrm{ml}$ of the extracted sample was transferred into the column. The extraction bottle was rinsed with the $1 \mathrm{ml}$ of pentane and added to the column as well. The eluent was collected with a $10 \mathrm{ml}$ graduated cylinder. Just prior to exposure of the sodium sulphate layer to air, pentane was added to the column in 1-2 $\mathrm{ml}$ increments. Accurately measured volume of $8 \mathrm{ml}$ of the eluant was collected and transferred into labelled glass vials with leflons rubber crimp caps for GC analysis. The sample was automatically detected and the amount of TPH was resolved at a particular chromatogram in $\mathrm{mg} / \mathrm{kg}$ soil sample Polycyclic aromatic hydrocarbons (PAHs) were quantitiated using an Agilent 6890N gas chromatograph with an Agilent 5973 Network mass spectrometer and Agilent 7683 B series autosampler. Selected ion monitoring was used to analyze the data while MSD ChemStation software was used for acquisition data. DB-5 MS fused-silica capillary column was applied with helium $(99.9 \%)$ as a carrier gas and at a flow rate of $1.5 \mathrm{ml} / \mathrm{min}$. The detector and injection port temperature was $250{ }^{\circ} \mathrm{C}$ and $230{ }^{\circ} \mathrm{C}$ respectively. The quantification was done using internal standard calibration curve method.

\subsubsection{Quality Assurance/control}

A procedural blank analysis was performed with every 3 samples to monitor interferences and cross-contamination. Each analysis was performed in quadruplicate and the experimental detection limit was $0.01 \mathrm{mg} / \mathrm{kg}$ dry matter for individual compounds.

\subsection{Enzyme Activities}

Catalase activity was determined by $\mathrm{KMnO}_{4}$ titration method with $\mathrm{H}_{2} \mathrm{O}_{2}$ as substrate. The mixture of $2 \mathrm{~g}$ soil, 40 $\mathrm{ml}$ distilled water and $5 \mathrm{ml}$ of $0.3 \% \mathrm{H}_{2} \mathrm{O}_{2}$ was shaken for 20 $\min$ at $25^{\circ} \mathrm{C}$. After filtration, $5 \mathrm{ml}$ of $1.5 \mathrm{~mol} / \mathrm{L} \mathrm{H}_{2} \mathrm{SO}_{4}$ was added to $10 \mathrm{ml}$ extract and the remaining $\mathrm{H}_{2} \mathrm{O}_{2}$ was measured by $0.1 \mathrm{~mol} / \mathrm{L} \mathrm{KMnO}_{4}$ solution. Catalase activity was expressed in $\mathrm{ml} 0.1 \mathrm{~mol} / \mathrm{L} \mathrm{KMnO}_{4}$ solution titrated / (g dry soil $20 \mathrm{~min}$ ). Soil hydrogen peroxidase was determined with titration method according to Alef and Nannipieri, [16].

\subsection{Statistical Analysis}

The samples were collected in quadruplicates and the concentration of each parameter was expressed as the arithmetic mean with standard deviation. The data were analyzed with SPSS software version 20, using two way analyses of variances (ANOVA) and the least standard deviations (LSD). $\mathrm{p}$ values $<0.05$ were considered as significant.

\section{Results and Discussion}

Table 1. pH levels of petroleum polluted soils and effect of application of macerated roots of TD and SJ

\begin{tabular}{|c|c|c|c|c|c|}
\hline GROUP & 1st day & 1st Week & 4th Week & 8th Week & 12th Week \\
\hline Group 1 & $8.10 \pm 0.24^{\text {ah }}$ & $8.25 \pm 0.19^{\text {ah }}$ & $8.08 \pm 0.39^{\text {ah }}$ & $8.41 \pm 0.62^{\text {ah }}$ & $8.17 \pm 0.22^{\text {ah }}$ \\
\hline Group 2 & $5.47 \pm 0.03^{\text {bh }}$ & $5.30 \pm 0.11^{\text {bh }}$ & $5.55 \pm 0.21^{\text {bh }}$ & $5.47 \pm 0.31^{\text {bh }}$ & $5.37 \pm 0.11^{\text {bh }}$ \\
\hline Group 3 & $6.01 \pm 0.08^{\text {ch }}$ & $6.71 \pm 0.27^{\text {dei }}$ & $7.20 \pm 0.16^{\text {ej }}$ & $7.27 \pm 0.12^{\text {dj }}$ & $7.40 \pm 0.21^{\text {ej }}$ \\
\hline Group 4 & $6.15 \pm 0.30^{\text {ch }}$ & $7.88 \pm 0.20^{\text {fi }}$ & $7.93 \pm 0.11^{\text {ai }}$ & $7.91 \pm 0.08^{\text {ei }}$ & $7.95 \pm 0.19^{\text {ai }}$ \\
\hline Group 5 & $5.90 \pm 0.11^{\text {ch }}$ & $6.04 \pm 0.13^{\text {ch }}$ & $6.64 \pm 0.20^{\text {ci }}$ & $6.72 \pm 0.07^{\text {ci }}$ & $6.70 \pm 0.25^{\text {ci }}$ \\
\hline Group 6 & $6.11 \pm 0.20^{\text {ch }}$ & $6.83 \pm 0.08^{\text {dgi }}$ & $6.91 \pm 0.24^{\text {dij }}$ & $7.03 \pm 0.09^{\text {dj }}$ & $7.09 \pm 0.03^{\text {dj }}$ \\
\hline Group 7 & $6.03 \pm 0.14^{\text {ch }}$ & $6.55 \pm 0.15^{\text {ei }}$ & $7.06 \pm 0.26^{\text {dj }}$ & $6.88 \pm 0.18^{\text {cj }}$ & $7.58 \pm 0.10^{\text {ek }}$ \\
\hline Group 8 & $6.10 \pm 0.10^{\text {ch }}$ & $6.94 \pm 0.09^{\text {gi }}$ & $7.31 \pm 0.23^{\text {ej }}$ & $7.60 \pm 0.11^{\text {fk }}$ & $7.77 \pm 0.13^{\text {ek }}$ \\
\hline
\end{tabular}

Values are means \pm standard deviations of quadruplicate determinations. Values with similar superscript letter(s) a-g down the column are not significantly different $(\mathrm{p}>0.05)$, while values with similar superscript letter(s) h-k across the group are not significantly different $(\mathrm{p}>0.05)$. 
Table 2. PAH $\left(\mathrm{mg} \mathrm{kg}^{-1}\right)$ levels of petroleum polluted soils and effect of application of macerated roots of TD and SJ

\begin{tabular}{|c|c|c|c|c|c|}
\hline GROUP & 1 st day & 1st Week & 4th Week & 8th Week & 12 th Week \\
\hline Group 1 & $1.47 \pm 0.09^{\mathrm{ag}}$ & $1.44 \pm 0.11^{\mathrm{ag}}$ & $1.65 \pm 0.29^{\mathrm{ag}}$ & $1.57 \pm 0.80^{\mathrm{ag}}$ & $1.50 \pm 0.24^{\mathrm{ag}}$ \\
\hline Group 2 & $11.32 \pm 0.52^{\mathrm{bg}}$ & $11.38 \pm 0.6^{\mathrm{bg}}$ & $11.57 \pm 0.77^{\mathrm{bg}}$ & $11.15 \pm 0.66^{\mathrm{bg}}$ & $10.99 \pm 1.0^{\mathrm{bg}}$ \\
\hline Group 3 & $9.3 \pm 1.08 \mathrm{~b}^{\mathrm{cdg}}$ & $7.71 \pm 0.20^{\mathrm{chl}}$ & $5.27 \pm 0.94^{\mathrm{ci}}$ & $4.13 \pm 0.04^{\mathrm{cj}}$ & $4.09 \pm 0.07^{\mathrm{cj}}$ \\
\hline Group 4 & $7.03 \pm 1.0^{\mathrm{eg}}$ & $6.04 \pm 0.52^{\mathrm{ch}}$ & $5.14 \pm 0.80^{\mathrm{chi}}$ & $4.29 \pm 0.15^{\mathrm{cij}}$ & $4.11 \pm 0.13^{\mathrm{cj}}$ \\
\hline Group 5 & $10.76 \pm 0.75^{\mathrm{bdg}}$ & $9.11 \pm 0.47^{\mathrm{dh}}$ & $7.21 \pm 0.12^{\mathrm{di}}$ & $7.04 \pm 0.61^{\mathrm{di}}$ & $7.09 \pm 0.07^{\mathrm{di}}$ \\
\hline Group 6 & $8.99 \pm 0.65^{\mathrm{cdg}}$ & $8.08 \pm 0.93^{\mathrm{egh}}$ & $7.01 \pm 0.33^{\mathrm{dhi}}$ & $6.81 \pm 0.22^{\mathrm{dij}}$ & $6.53 \pm 0.04^{\mathrm{ej}}$ \\
\hline Group 7 & $10.24 \pm 0.87^{\mathrm{bdg}}$ & $8.53 \pm 0.17^{\mathrm{deh}}$ & $5.58 \pm 0.70^{\mathrm{ci}}$ & $4.31 \pm 0.46^{\mathrm{cj}}$ & $4.13 \pm 0.11^{\mathrm{cj}}$ \\
\hline Group 8 & $8.7 \pm 0.49^{\mathrm{cg}}$ & $7.45 \pm 0.60^{\mathrm{fg}}$ & $5.00 \pm 0.06^{\mathrm{ch}}$ & $4.05 \pm 0.17^{\mathrm{ci}}$ & $3.97 \pm 0.10^{\mathrm{ci}}$ \\
\hline
\end{tabular}

Values are means \pm standard deviations of quadruplicate determinations. Values with similar superscript letter(s) a- $\mathrm{f}$ down the column are not significantly different $(p>0.05)$, while values with similar superscript letter(s) g-i across the group are not significantly different $(p>0.05)$.

Table 3. TPH (mg/kg) levels of petroleum polluted soils and effect of application of macerated roots of TD and SJ

\begin{tabular}{|c|c|c|c|c|c|}
\hline GROUP & 1st day & 1 st Week & 4th Week & 8th Week & 12 th Week \\
\hline Group 1 & $1.07 \pm 0.03^{\mathrm{ag}}$ & $1.13 \pm 0.01^{\mathrm{ag}}$ & $0.92 \pm 0.06^{\mathrm{ag}}$ & $1.13 \pm 0.02^{\mathrm{ag}}$ & $1.04 \pm 0.03^{\mathrm{ag}}$ \\
\hline Group 2 & $5247.09 \pm 82.5^{\mathrm{bg}}$ & $5252.36 \pm 31.7^{\mathrm{bg}}$ & $5240.11 \pm 73.8^{\mathrm{bg}}$ & $5243.55 \pm 63.0^{\mathrm{bg}}$ & $5250.06 \pm 21.6^{\mathrm{bg}}$ \\
\hline Group 3 & $5082.62 \pm 25.8^{\mathrm{cg}}$ & $4628.44 \pm 33.0^{\mathrm{ch}}$ & $3911.70 \pm 84.1^{\mathrm{ci}}$ & $3647.04 \pm 61.5^{\mathrm{cj}}$ & $3341.16 \pm 27.7^{\mathrm{ck}}$ \\
\hline Group 4 & $4890.17 \pm 32.2^{\mathrm{dg}}$ & $4559.30 \pm 67.7^{\mathrm{dh}}$ & $3425.81 \pm 11.20^{\mathrm{di}}$ & $3027.21 \pm 41.1^{\mathrm{dj}}$ & $2892.43 \pm 50.1^{\mathrm{dk}}$ \\
\hline Group 5 & $5111.90 \pm 53.5^{\mathrm{cg}}$ & $4804.61 \pm 52.1^{\mathrm{eh}}$ & $4389.40 \pm 71.1^{\mathrm{ei}}$ & $3969.55 \pm 71.7^{\mathrm{ej}}$ & $3646.71 \pm 49.2^{\mathrm{ek}}$ \\
\hline Group 6 & $5046.18 \pm 76.4^{\mathrm{ceg}}$ & $4696.35 \pm 68.4^{\mathrm{ch}}$ & $4155.40 \pm 48.9^{\mathrm{ei}}$ & $3597.22 \pm 60.4^{\mathrm{cj}}$ & $3289.06 \pm 31.3^{\mathrm{ck}}$ \\
\hline Group 7 & $5096.82 \pm 12.2^{\mathrm{cg}}$ & $4641.25 \pm 30.8^{\mathrm{ch}}$ & $4024.61 \pm 66.3^{\mathrm{ci}}$ & $3951.92 \pm 74.0^{\mathrm{ei}}$ & $3702.61 \pm 50.4^{\mathrm{ej}}$ \\
\hline Group 8 & $5003.75 \pm 38.1^{\mathrm{eg}}$ & $4549.11 \pm 12.2^{\mathrm{dh}}$ & $3779.31 \pm 24.8^{\mathrm{fi}}$ & $3661.84 \pm 52.5^{\mathrm{ci}}$ & $3351.70 \pm 67.8^{\mathrm{cj}}$ \\
\hline
\end{tabular}

Values are means \pm standard deviations of quadruplicate determinations. Values with similar superscript letter(s) a-f down the column are not significantly different $(\mathrm{p}>0.05)$, while values with similar superscript letter(s) $g$-k across the group are not significantly different $(\mathrm{p}>0.05)$.

Table 4. Catalase $\left(\mathrm{ml} \mathrm{g}^{-1}\right)$ levels of petroleum polluted soils and effect of application of macerated roots of TD and SJ

\begin{tabular}{|c|c|c|c|c|c|}
\hline GROUP & 1st day & 1st Week & 4th Week & 8th Week & 12 th Week \\
\hline Group 1 & $6.90 \pm 0.55^{\text {ah }}$ & $6.88 \pm 0.38^{\text {ah }}$ & $6.71 \pm 0.73^{\text {ah }}$ & $7.07 \pm 0.38^{\text {ah }}$ & $6.96 \pm 0.57^{\text {ah }}$ \\
\hline Group 2 & $0.16 \pm 0.01^{\text {bh }}$ & $0.18 \pm 0.01^{\text {bh }}$ & $0.18 \pm 0.009^{\text {bh }}$ & $0.17 \pm 0.01^{\text {bh }}$ & $0.18 \pm 0.002^{\text {bh }}$ \\
\hline Group 3 & $4.19 \pm 0.31^{\mathrm{fj}}$ & $4.40 \pm 0.49^{\mathrm{di}}$ & $4.45 \pm 0.16^{\mathrm{fi}}$ & $5.27 \pm 0.38^{\mathrm{fh}}$ & $5.59 \pm 0.31^{\mathrm{eh}}$ \\
\hline Group 4 & $4.52 \pm 0.27^{\mathrm{ej}}$ & $4.60 \pm 0.57^{\mathrm{dj}}$ & $4.96 \pm 0.70^{\mathrm{ej}}$ & $5.85 \pm 0.66^{\mathrm{ei}}$ & $6.13 \pm 0.44^{\mathrm{ch}}$ \\
\hline Group 5 & $3.40 \pm 0.10^{\mathrm{dk}}$ & $3.71 \pm 0.22^{\mathrm{cj}}$ & $3.75 \pm 0.29^{\mathrm{dj}}$ & $4.01 \pm 0.60^{\mathrm{di}}$ & $5.06 \pm 0.17^{\mathrm{dh}}$ \\
\hline Group 6 & $3.88 \pm 0.19^{\mathrm{ck}}$ & $3.86 \pm 0.40^{\mathrm{ck}}$ & $4.03 \pm 0.33^{\mathrm{cj}}$ & $4.77 \pm 0.97^{\mathrm{ci}}$ & $5.64 \pm 0.30^{\mathrm{eh}}$ \\
\hline Group 7 & $3.78 \pm 0.24^{\mathrm{cjk}}$ & $3.60 \pm 0.14^{\mathrm{ck}}$ & $3.98 \pm 0.23^{\mathrm{cgj}}$ & $4.48 \pm 0.56^{\mathrm{ci}}$ & $5.21 \pm 0.13^{\mathrm{dh}}$ \\
\hline Group 8 & $3.92 \pm 0.11^{\mathrm{ck}}$ & $3.82 \pm 0.26^{\mathrm{ck}}$ & $4.31 \pm 0.44^{\mathrm{fgj}}$ & $5.15 \pm 0.42^{\mathrm{fi}}$ & $5.87 \pm 0.52^{\mathrm{ech}}$ \\
\hline
\end{tabular}

Values are means \pm standard deviations of quadruplicate determinations. Values with similar superscript letter(s) a-g down the column are not significantly different $(\mathrm{p}>0.05)$, while values with similar superscript letter(s) h-k across the group are not significantly different $(\mathrm{p}>0.05)$.

Table 5. Peroxidase $\left(\mathrm{ml} \mathrm{g}^{-1}\right)$ levels of petroleum polluted soils and effect of application of macerated roots of TD and SJ

\begin{tabular}{|c|c|c|c|c|c|}
\hline GROUP & 1st day & 1st Week & 4th Week & 8th Week & 12th Week \\
\hline Group 1 & $0.21 \pm 0.03^{\mathrm{bg}}$ & $0.22 \pm 0.01^{\mathrm{bg}}$ & $0.23 \pm 0.02^{\mathrm{bg}}$ & $0.22 \pm 0.01^{\mathrm{bg}}$ & $0.23 \pm 0.03^{\mathrm{bg}}$ \\
\hline Group 2 & $0.06 \pm 0.02^{\mathrm{ag}}$ & $0.04 \pm 0.01^{\mathrm{ag}}$ & $0.05 \pm 0.01^{\mathrm{ag}}$ & $0.04 \pm 0.00^{\mathrm{ag}}$ & $0.05 \pm 0.01^{\mathrm{ag}}$ \\
\hline Group 3 & $0.12 \pm 0.02^{\mathrm{ch}}$ & $0.14 \pm 0.03^{\mathrm{deh}}$ & $0.13 \pm 0.02^{\mathrm{chh}}$ & $0.17 \pm 0.01^{\mathrm{dg}}$ & $0.19 \pm 0.01^{\mathrm{edg}}$ \\
\hline Group 4 & $0.16 \pm 0.03^{\mathrm{dh}}$ & $0.15 \pm 0.02^{\mathrm{dh}}$ & $0.16 \pm 0.00^{\mathrm{dh}}$ & $0.18 \pm 0.01^{\mathrm{dg}}$ & $0.20 \pm 0.01^{\mathrm{dg}}$ \\
\hline Group 5 & $0.11 \pm 0.02^{\mathrm{ch}}$ & $0.11 \pm 0.00^{\mathrm{ch}}$ & $0.10 \pm 0.01^{\mathrm{ch}}$ & $0.10 \pm 0.00^{\mathrm{ch}}$ & $0.16 \pm 0.02^{\mathrm{cfg}}$ \\
\hline Group 6 & $0.10 \pm 0.01^{\mathrm{ci}}$ & $0.11 \pm 0.01^{\mathrm{ci}}$ & $0.11 \pm 0.01^{\mathrm{ci}}$ & $0.13 \pm 0.03^{\mathrm{ch}}$ & $0.18 \pm 0.01^{\mathrm{ceg}}$ \\
\hline Group 7 & $0.10 \pm 0.01^{\mathrm{ch}}$ & $0.09 \pm 0.02^{\mathrm{ch}}$ & $0.10 \pm 0.02^{\mathrm{ch}}$ & $0.11 \pm 0.02^{\mathrm{ch}}$ & $0.15 \pm 0.02^{\mathrm{fg}}$ \\
\hline Group 8 & $0.10 \pm 0.00^{\mathrm{ch}}$ & $0.11 \pm 0.03^{\text {ch }}$ & $0.11 \pm 0.01^{\mathrm{ch}}$ & $0.17 \pm 0.03^{\mathrm{dg}}$ & $0.18 \pm 0.01^{\mathrm{ceg}}$ \\
\hline
\end{tabular}

Values are means \pm standard deviations of quadruplicate determinations. Values with similar superscript letter(s) a-f down the column are not significantly different $(\mathrm{p}>0.05)$, while values with similar superscript letter(s) g-i across the group are not significantly different $(p>0.05)$. 
Table 1 presents the $\mathrm{pH}$ of polluted soils after 12 weeks of maceration with Tithonia diversifolia and Strachytarpheta jamaicensis. The table shows a significant $(\mathrm{p}<0.05)$ reduction in the $\mathrm{pH}$ of the crude oil contaminated soil (G2) when compared to the uncontaminated soils (G1). However, no time dependent significant change in the $\mathrm{pH}$ of both the contaminated and uncontaminated soils was recorded. On application of the macerated roots, the $\mathrm{pH}$ of the contaminated soils was significantly higher than the contaminated but unremediated soils. Further, no significant change on the $\mathrm{pH}$ of the remediated soils was recorded after the application of the various macerated roots at distinct quantities. After 1 week of application of $\mathrm{TD}$ the $\mathrm{pH}$ of the soils significantly increased when compared to that of the 1 st day, however, the soil samples containing $500 \mathrm{~g}$ of macerated roots of TD recorded significantly higher $\mathrm{pH}$. Also, after the 1 st week, the application of $250 \mathrm{~g}$ of macerated roots of SJ, produced the least remediative effect on $\mathrm{pH}$, while the effect of $500 \mathrm{~g}$ macerated root of SJ on the $\mathrm{pH}$ was similar to that of $250 \mathrm{~g}$ TD. The $500 \mathrm{~g}$ application of TD provided the most significant restoration of the $\mathrm{pH}$ levels on the 4th week, while the $\mathrm{pH}$ levels of the soils remediated with $250 \mathrm{~g}$ of macerated roots of TD and $500 \mathrm{~g}$ of SJ were comparable to that for $500 \mathrm{~g}$ of the mixture of TD and SJ, and $250 \mathrm{~g}$ of both mixtures respectively. No significant effect was obtained by extending the experimental duration from the 8th -12 th week in the $\mathrm{pH}$ levels of all the experimental groups. Further, the results presented in Table 1 indicated the best $\mathrm{pH}$ restoration effect was obtained on administration of $500 \mathrm{~g}$ of macerated roots of TD, for the 8th and 12th week. Osuji and Nwoye, [21] opined that the production of organic acids resulting from the degradation of the hydrocarbons by microorganisms could be the cause of the reduction in pH. Obasi et al. [20] similarly showed that amendment of crude oil polluted soils significantly increases the $\mathrm{pH}$ levels.

Table 2 shows the results of PAH contents in polluted, unpolluted, and polluted but remediated soils at $24 \mathrm{~h}, 1$ week, 4 weeks, 8 weeks and 12 weeks duration. The application of $500 \mathrm{~g}$ macerated roots of TD produced the best decontamination effect on the PAH contents of all the oil polluted soil samples evaluated on the first day. The PAH contents of the unpolluted soils in this study, were higher than that reported in the study of Ogoko [22], while the PAH contents of soils within the vicinity of Nigerian National Petroleum Corporation (NNPC) was comparable to those recorded in this present study for Ohaji Egbema. The assessments carried out on the 7th day showed that increasing the quantity of the macerated roots of TD from $250 \mathrm{~g}$ to $500 \mathrm{~g}$ was insignificant to the decontamination of $\mathrm{PAH}$. The result further indicated that $500 \mathrm{~g}$ macerated root of TD produced the most effective PAH mop up on the 7th day, that continuously decreased with increment in experimental duration from 4 weeks to 8 weeks, while further increment in experimental duration had no significant effect on the PAH levels. Similar to the results obtained on the 4th week, increment in amount of the macerated roots of the plants had no significant effect on the PAH levels after 8 weeks, with TD, and the mixture of $\mathrm{TD}$ and SJ, proving most effective in reducing the PAH levels. Further, apart from a significant reduction in $\mathrm{PAH}$ levels on increment of the amount of the applied macerated roots SJ from $250 \mathrm{~g}$ to $500 \mathrm{~g}$, there was no observable significant effect of extending the experimental duration from 8 weeks to 12 weeks. Numerous researchers have identified the effectiveness of inhabiting microorganisms on the roots of these plants, for the degradation of specific PAH [23] [24]. Also, in support to this study, Edema et al. [25] have shown the potentials of dead vegetables and earthworm in the reduction of $\mathrm{PAH}$ in crude oil contaminated soils.

The Total Petroleum Hydrocarbon contents of unpolluted, polluted, and remediated soils are presented in Table 3. The result showed a significant increase in the TPH content on the 1st day, as a result of crude oil pollution, which significantly reduced on application of the macerated roots of TD and SJ. TD (500 g) showed the highest remediation effect on the TPH content of the crude oil polluted soil, followed by $500 \mathrm{~g}$ of the mixture of macerated roots of TD and SJ on the first day. Extending the experimental duration to 4 weeks also produced a significant reduction in the TPH contents of the remediated soils when compared to the results for the 1st and 7th day. On the 4th week, increment in quantity of applied macerated roots of TD, and the mixture of macerated roots of TD and SJ, from $250 \mathrm{~g}$ to $500 \mathrm{~g}$ significantly reduced the TPH contents of the soil.. Application of $500 \mathrm{~g}$ of TD achieved the highest decontamination of TPH in this study, showing a $44.91 \%$ TPH reduction. Cynodon dactylon L. (Bermuda grass) as reported by Onwuka et al. [26] produced a greater reducing effect $(86.2 \%)$ on TPH contents of oil polluted soils, than that of $500 \mathrm{~g}$ of TD presented in this study. The TPH levels presented in this study is also higher than the maximum permissible limit of $1000 \mathrm{mg} / \mathrm{kg}$ recommended by DPR [27] and NSW [28]. Further, the reports of Alinnor and Nwachukwu, [29] for the TPH contamination of soil samples in Rivers State, Nigeria were much lower than values presented in this study. In contrast, the reports for the TPH contamination of the soil of coastal Mexican refinery according to Iturbe et al. [30], was higher than those recorded at polluted soils from Ohaji Egbemacommunity recorded in this study. TPH contaminated soils require adequate decontamination measures due to their systemic toxicity to the human body.

The soil catalase levels of crude oil polluted soils obtained from Ohaji Egbema, and effects of phytoremediation using macerated roots of TD and SJ on the catalase levels are presented in Table 4. The result indicated significantly decreased soil catalase levels of the polluted soils when compared to the unpolluted soils. Soil catalase activity relates to the metabolic activities of 
aerobic microorganisms as well as the number of aerobic microorganisms, and soil fertility. Hence, the low levels in soil catalase of the polluted soils may have resulted from an inhibition of the metabolic activities of the aerobic microorganisms. This agrees with the reports of Leilei et al. [31] that showed that pollution of soil by petroleum products decreases the catalase activities. Also, in this study, the increment in experimental duration from the 1st day to the 12th weeks had no significant effect on the catalase levels for both the unpolluted, and polluted but unremediated soil samples. The application of the macerated roots of the plants used for this study significantly elevated the catalase levels. However, the highest level of catalase obtained on the first day occurred as a result of the application $500 \mathrm{~g}$ of TDThe result obtained on the 1st week showed that the increment in the amount of applied macerated roots from $250 \mathrm{~g}$ to $500 \mathrm{~g}$ had no significant effect on the catalase levels, while that of the 4 th, 8 th, and 12 th week showed a quantity dependent effect of the macerated roots on amount of catalase detected. This could imply that since the macerated roots provides the necessary microorganisms required to metabolize these contaminants from the oil, or provide exudates for soil microorganisms, increasing the applied amount in order to increase the microbial load only proves effective in metabolizing the contaminants, around the 4th week. Further, the application of $500 \mathrm{~g}$ of TD showed the most potential $(88.07 \%)$ in restoring the depleted catalase activities, which might be fully restored beyond the experimental duration attained in this present study.

The results of the hydrogen peroxidase content of remediated and unremediated soil samples were represented in Table 5. At all the experimental periods, both uncontaminated and contaminated but not remediated soils, maintained uniform levels of peroxidase. The results showed that the application of the macerated plant roots on the polluted soils significantly elevated the peroxidase levels. This agrees the reports of Hirata et al. [32], Fediuc and Erdei [33], and Angelica and Leonor [34] that demonstrated that on account of response to chemical stress, plant roots release high amounts of peroxidases into the soil. For the first day, no significant difference was recorded for the peroxidase levels among all the soils treated with SJ, $250 \mathrm{~g}$ of TD, and the mixture of both plants, which was also similar to the results obtained for the first week, except that the catalase levels of soils remediated with $250 \mathrm{~g}$ of TD was only similar to that of the $500 \mathrm{~g}$ of $\mathrm{TD}$, and the mixture. At the 4 th week, application of $500 \mathrm{~g}$ of TD producing the highest elevation of catalase levels of the polluted soils. Similarly, increment of the experimental period to 8 and 12 weeks showed no difference between the peroxidase levels obtained on application of $250 \mathrm{~g}$ and 500 $\mathrm{g}$ of the macerated roots, with the exception of the experimental setups containing the mixture of both macerated roots. Also, for the polluted soils distinctly treated with $250 \mathrm{~g}, 500 \mathrm{~g}$ of TD, and $500 \mathrm{~g}$ of the mixture of both TD and SJ, the peroxidase level only significantly increased on the 8th and 12th week of study whereas the catalase levels of soils remediated with $250 \mathrm{~g}$ of SJ, and $250 \mathrm{~g}$ of the mixture of both TD and SJ produced significant elevation of peroxidase levels only at the 12th week.. In line with the suggestions of Salt et al. [35] the microbes at the roots of these plants enabled the volatilization of these PAHs thereby accelerating the remediation process.

\section{Conclusions}

Soils from Ohaji Egbema have been shown to have elevated $\mathrm{pH}, \mathrm{PAH}, \mathrm{TPH}$, and low levels of catalase and peroxidase. Also, application of the macerated roots of 500 $\mathrm{g}$ of TD restored the altered $\mathrm{pH}$ while the TD and SJ both lowered the PAH and TPH and elevated the catalase and peroxidase levels, with 12 weeks of application of $500 \mathrm{~g}$ macerated roots of $\mathrm{TD}$, proving most effective.

\section{REFERENCES}

[1] Gianfreda L, Rao MA, Piotrowska A, Palumbob G, Colombob, C. Soil enzyme activities as affected by anthropogenic alterations;intensive agricultural practices and organic pollution. Sci Total Environ 341 2005;265-279 PMID; 15833257

[2] Osam MU. Evaluation of the selected wild type legumes in remediation of crude oil contaminated agricultural soils Phd dissertation Nigeria, 2011; Biochemistry Department, University Of Port Harcourt

[3] Johnsen AR, Wick, LY, Harms H. Principles of microbial PAH-degradation in soil. Environmental Pollution- Journal 2005;133(1), 71-84

[4] Olatunbosun SS, Oluwadayo OS, Eddy YZ. Concentrations of polycyclic aromatic hydrocarbons in soils of a mangrove forest affected by forest fire. Toxicological \& Environmental Chemistry 2011;93(3), 450-461

[5] International Agency for Research in Cancer. Monographs on the evaluation of the carcinogenic risk of chemical to humans polycyclic aromatic compounds;Part I Environmental data 1983;32, Lyon, France

[6] Rauckyte T, Slawomir Z, Zenon P, Adekunle O Determination of oil and grease, total petroleum hydrocarbons and volatile aromatic compounds in soil and sediment samples. Journal of Environmental Engineering and Landscape Management 2010;18(3), 163-169

[7] Costello, J. Morbidity and Mortality Study of Shale Oil Workers in the United States. Environmental Health Perspectives, 1979;30, pp 205-208,

[8] Baležentiené, L. Hydrolases related to $\mathrm{C}$ and $\mathrm{N}$ cycles and soil fertility amendment; responses to different management styles and agro-ecosystems. Pol J Environ Stud 2012;21(5): 1153-1159 
[9] Gianfreda L, Bollag JM. Influence of natural and anthropogenic factors on enzyme activity in soil In;Soil Biochemistry (1stedn) 1996;Marcel Dekker Inc, New York, Basel, Hong Kong

[10] Abbey E., Anthony N. Effect of Crude oil spillage on soil and microbial properties of a tropical rainforest. Institute of Pollution studies and Biological Sciences, Imo state University Owerri, 1994; 3ed, Pacific Publication.

[11] Nwachukwu AN., Osuagwu JC. Effects of Oil Spillage on Groundwater Quality in Nigeria, American Journal of Engineering Research (AJER), 2014;3(6), pp-271-274

[12] Balba MT, Awadhi N, Al-Daher R. Bioremediation of oil-contaminated soil; Microbiological methods for feasibility assessment and field evaluation. J Microbiol Methods 1998;32: 155- 164

[13] Vidali M. Bioremediation;An overview, Pure Applied Chem 2001;73(7): 1163-1172

[14] Leung M. Bioremediation;techniques for cleaning up a mess, J Biotechnol, 2004;2: 18-22

[15] Essien EB, Ifeanacho MO, Nwachukwu GA. The impact of Cow Dung Augmentation for Remediation of Crude Oil Polluted Soil by Eleusine indica, J. Appl. Sci. Environ. Manage. 2015;19 (1) 103 - 107

[16] Alef K, Nannipieri P. Methods in applied soil microbiology and biochemistry[M] London 1995;Academic Press

[17] Dubey RC. A textbook of Biotechnology 2009;S Chandy and Company Ltd Ram Nagar, New Delhi - 110055

[18] Olukunle OF. Microbial Population and Physicochemical Properties of Oil-polluted sites in selected areas of Niger Delta, Nigeria 2013;3(13)

[19] Eneje RC, Nwagbara C, Uwumarongie-Ilori EG. Amelioration of chemical properties of crude oil contaminated soil using compost from Calapoigonium mucunoides and poultry manure. International Research Journal of Agricultural Science and Soil Science 2012;2(6): 246-251

[20] Obasi NA, Eberechukwu E, Anyanwu DI, Okorie UC. Effects of organic manures on the physicochemical properties of crude oil polluted soils. African Journal of Biochemistry Research 2013;7(6);67-75

[21] Osuji LC, Nwoye I. An appraisal of the impact of petroleum hydrocarbons on soil fertility; the Owaza experience. Afr J Agric Res 2007;2(7);318-324

[22] Ogoko EC. Evaluation of Polycyclic Aromatic Hydrocarbons, Total Petroleum Hydrocarbons and Some Heavy Metals in Soils of Nnpc Oil Depot Aba Metropolis, Abia State, Nigeria. IOSR Journal of Environmental Science, Toxicology and Food Technology (IOSR-JESTFT) 2014;8(5), PP 21-27

[23] Prenafeta-Boldú FX, Vervoort J, Grotenhuis JTC, van
Groenestijn JW. Substrate Interactions during the Biodegradation of Benzene, Toluene, Ethylbenzene, and Xylene (BTEX) Hydrocarbons by the Fungus Cladophialophora sp Strain T1. Appl Environ Microbiol 2002;68(6): 2660-2665

doi;101128/AEM6862660-26652002

[24] da Silva M, Cerniglia CE, Pothuluri JV. Screening filamentous fungi isolated from estuarine sediments for the ability to oxidize polycyclic aromatic hydrocarbons. World Journal of Microbiology and Biotechnology 2003, 19(4), pp 399-405

[25] Edema CU, Idu TE, Edema MO. Remediation of soil contaminated with polycyclic aromatic hydrocarbons from crude oil. African Journal of Biotechnology, 2011;10(7), pp 1146-1149, DOI;105897/AJB101308

[26] Onwuka F, Ndidi N, Anosike E. Determination of Total Petroleum Hydrocarbon (TPH)and some Cations $(\mathrm{Na}+$, $\mathrm{Ca} 2+$ and $\mathrm{Mg} 2+$ ) in a Crude Oil Polluted Soil and possible Phytoremediation by Cynodon dactylon L (Bermuda grass), Journal of Environment and Earth Science 2012;2(6):13

[27] DPR. Environmental guidelines and standards for the petroleum industry in Nigeria (Revised edition) Department of Petroleum Resources, Ministry of Petroleum and Mineral Resources 2002; Lagos pp 30-58

[28] National Environmental Protection Measurement of Australia, NSW, 1999

[29] Alinnor IJ, Nwachukwu MA. Determination of total petroleum hydrocarbon in Soil and groundwater samples in some communities in Rivers State. Nigeria J Environmental Chemical and Ecotoxicology 2013;5(11):292-297

[30] Iturbe R, Flores RM, Flores CR, Torres LG. TPH contaminated Mexican refinery soil; Heaith risk assessment and the first year of changes. Environ Monit and Assess 2004;91(1-3);237-255

[31] Leilei Z, Mingxin H, Zhu S. Enzymatic remediation of the polluted crude oil by Rhodococcus. African Journal of Microbiology Research, 2012;6(6), pp 1213-1220

[32] Hirata T, Ashida Y, Mori H, Yoshinaga D, Goad LJ. A 37 $\mathrm{KDa}$ peroxidase secreted from liverworts in response to chemical stress. Phytochem 2000;55: 197202

[33] Fediuc E, Erdel L. Physiological and biochemical aspects of cadmium toxicity and protective mechanisms induced in Phragmites australis and Typha latifolia. J Plant Physiol 2010;159: $265-271$

[34] Angelica RD, Leonor AGZ. Phenoloxidases activity in root system and their importance in the phytoremediation of organic contaminants. Journal of Environ Chem Eotoxic $2012 ; 4(3): 35-40$

[35] Salt DE, Smith RD, Raskin I. Phytoremediation. Rev Plant Physiol Mol Biol 1998; 49: 643. 